Research Article

\title{
Kinetics and mechanistic study of oxidation of paracetamol: an accelerated catalytic approach
}

\author{
Reena Negi ${ }^{1}$ Bhawana Jain $^{2} \cdot$ Sunita Singh ${ }^{2} \cdot$ Ajaya Kumar Singh ${ }^{2} \cdot$ Anupama Asthana $^{2}$
}

(c) Springer Nature Switzerland AG 2019

\begin{abstract}
In the present paper, a simple, and novel method for the abatement of paracetamol (PA) in aqueous system into environmental friendly compound benzoquinone at $308 \mathrm{~K}$ has been described, and was accelerated by simple, and inexpensive catalyst $\mathrm{Cu}(\mathrm{II}) / \mathrm{Ni}(\mathrm{II})$. A comparative assessment between $\mathrm{Cu}(\mathrm{II})$ and $\mathrm{Ni}(\mathrm{II})$ catalyzed, abatement of PA by CAT was performed. It has been determined that there are very little change in rate of reaction for both $\mathrm{Cu}(\mathrm{II}) / \mathrm{Ni}$ (II) catalyzed degradation of PA. All the kinetics parameters, i.e. the effect of change in concentrations of chloramine-T (CAT), sodium hydroxide, paracetamol, catalyst, added $p$-toluenesulfonamide, electrolyte etc. have been studied, and measured carefully. Reaction had been studied in the range of temperature 303-323 K. On the basis of kinetic data obtained a satisfactory mechanism has been proposed. And it was deduced that, presently used process was a tenable technique for the degradation of PA. Main abatement product was confirmed by GC-MS analysis technique.
\end{abstract}

\section{Graphic abstract}

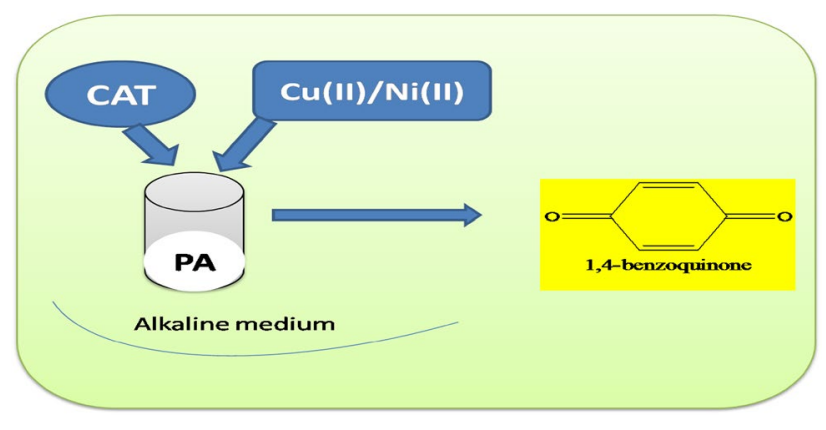

Keywords Kinetics · Degradation · Chloramine-T · Paracetamol $\cdot \mathrm{Ni}(\mathrm{II}) / \mathrm{Cu}(\mathrm{II})$ chloride catalysis

Electronic supplementary material The online version of this article (https://doi.org/10.1007/s42452-019-1365-8) contains supplementary material, which is available to authorized users.

Ajaya Kumar Singh, ajayaksingh_au@yahoo.co.in | ${ }^{1}$ Department of Applied Chemistry, Echelon Institute of Technology, Faridabad, Haryana, India. ${ }^{2}$ Department of Chemistry, Govt. V. Y. T. PG. Autonomous College, Durg, Chhattisgarh 491001, India. 


\section{Introduction}

Sometime, water contains an unwanted substance that makes it no longer suitable for use. Its existence make threaten to drinking water, and finally harsh the living organism $[1,2]$. It will affect the liver, kidney, lung etc. $[3,4]$. These days, due to increases of civilization uses of drugs, fertilizers, cosmetics, paints continuously pollute the water [5]. Different contaminants that comes from various industries i.e. pharmaceutical [6, 7], petroleum [8], textile [9], steel [10], pulp and paper mill [11] etc. are generally dispose into the water, which finally make water for unfit for domestic utilization.

Among which, we have been found that pharmaceutical waste generated by industries; expel its waste in water bodies, and sometime people through non-used medicine into open land or in garbage. So, the pharmaceutical wastes that mix into water convert into many toxic substances, and had toxic effect on both human and aquatic life. Some of real wastewater sample i.e. drug present in German ground water, and synthetic drug containing wastewater such as amoxicillin, ciprofloxacin, ofloxacin and atanolol, and captopril were degrade by various oxidation process [12-16].

Paracetamol ( $N$-acetyl-p-aminophenol) has a significant role because of analgesic and antipyretic action. This non narcotic analgesic drug can alternatively used as in place of asprin. It is most widely used medicine for the relief of pain i.e. headache, backache, and postoperation. On the other hand, when it consumed in overdose, it may result in severe hepatic toxicity or even death. Its determination process includes various spectroscopic methods [17-19]. However, less attention has been given the choice to use an oxidizing agent for its determination [20-26]. Paracetamol has been reported to be present in sewage treatment plant effluents up to a concentration of $6.0 \mu \mathrm{g} / 1$ [27].

$\mathrm{N}$-haloamine compounds have halonium ions and nitrogen anions, so it acts as both the base, and nucleophile [28-33]. The well known leading member of $\mathrm{N}$-haloniumcompounds is sodium- $\mathrm{N}$-chloro-4-methylbenzensulfonamide, it is also known as chloramine-T (CAT). This reagent has been turned to account as an oxidant for various substrates [34-40]. As a result, these compounds are capable for molecular changes.

The elements, which can easily form cation, and have partially filled d-orbitals are reported as efficient catalyst in various organic oxidation reactions [41-50], copper compound are abundance in nature, biological media, so it consider a major role in oxidation chemistry and it also act as catalyst in many oxidation reaction [51]. In 1961, Corey reported that cis hydrogenation of olefins was possible in the presence of hydrazine, hydrogen peroxide, and trace amounts of $\mathrm{Cu}$ (II) [52]. Interestingly, he reported that the reaction occurred "instantaneously". Thus, the rate of reaction in the presence of $\mathrm{Cu}(\mathrm{II})$ would have to be much faster [53-60]. An iodometric determination of CAT employing copper(II) as catalyst has also been reported [61]. Since $\mathrm{Cu}(\mathrm{II})$ is known to form $\mathrm{Cu}(\mathrm{III})$, if oxidized and stabilized by suitable ligands in alkaline solutions, we thought the mechanistic study involving $\mathrm{Cu}$ (II) as a catalyst in oxidation with CAT might enable us to know more of the chemistry of $\mathrm{Cu}$ (III). Another catalyst nickel used in present work is a low cost catalyst with high activity [62], in comparison with the more active palladium or platinum $[63,64]$, that could mask to some extent the role of the support. Amine is be synthesized by Hydrogenation of nitriles bears industrial interest, given their wide spectrum of industrial application, which can be involved in the synthesis of surfactants, fungicides, chelating agents, surfactants etc. [65]. The result from laboratory, on the self decomposition of $\mathrm{Ni}(\mathrm{II})$-peroxomonosulfate in the $\mathrm{pH}$ range of approximately 3.4-5.9, suggest that the metal ion-catalyzed reaction proceeds through a molecular mechanism with a metal peroxide intermediate. Metallopeptides of the type Ni(II)-XaaXaa-His, where Xaa is any amino acid, have been shown to mediate cleavage of DNA [66-74]. Thendral et al. [75] have shown the role of $\mathrm{Ni}(\mathrm{II})$ in the oxidation of glycylglycine dipeptide by peroxomonosulfate. For the analytical chemists kinetic methods are of best option for drug analyses because it provides the sensitive determination by using very simple instruments. Thus, the basic principle of kinetic method is to measure, the change in concentration of reactants with time, catalyst can increase the reaction rate. Recent advance in analytical techniques have facilitated measurements of very low concentration of drug [76].

By close look over the literature, we endow that there are no reports available for the oxidation of PA by CAT in the presence of either $\mathrm{Cu}$ (II) or $\mathrm{Ni}(\mathrm{II})$ catalyzed reaction in alkaline medium, and its comparative studies, so we prepared this manuscript.

\section{Experimental}

\subsection{Materials and instrumentation}

Pharmaceutical wastewater was synthetically prepared every day, by dissolving, an appropriate amount of recrystallized PA sample in deionized water. Similarly, stock solutions of CAT (Loba, AR), Cu(II) and Ni(II) of E. Merck, were prepared, and standardized idometrically. Sodium perchlorate, $\mathrm{NaOH}$ (E. Merck) was used without further purification by preparing their solutions. Analytical reagent grade chemicals, and doubly distilled water were used throughout the investigation. Degradation processes 
were recorded using UV-Vis spectrophotometer computer controlled, and $\lambda_{\max }$ for PA was obtained at $240 \mathrm{~nm}$. And product of reaction was determined by GCMS.

\subsection{Oxidation method}

To sum up, synthetic pharmaceutical wastewater was oxidize by CAT at laboratory (bench) scale. A probe study of oxidation of PA in alkaline medium in the presence of catalyst $(\mathrm{Cu}(\mathrm{II}) / \mathrm{Ni}(\mathrm{II}))$ were placed in a dark (black) vessel at constant temperature, $308 \mathrm{~K}$ with all reactants in required concentrations. A kinetic studies had been done under pseudo first-order conditions with [PA] $\gg$ [CAT]. The reaction was initiated by rapid addition of pre-equilibrated PA to the reaction mixture containing all reactants in appropriate amount. The reaction was monitored by idometric determination of unconsumed [CAT] at various time intervals.

In view of the ubiquitous contamination of basic solutions by carbonate, the rate of reaction was studied by the addition of carbonate. Added carbonate had no effect on the reaction rate. Fresh solutions were always used during the experiments.

\section{Results and discussion}

\subsection{Stoichiometry and product analysis}

Concentration of CAT required $2 \mathrm{~mol}$ for the oxidation of $1 \mathrm{~mol}$ of PA when taking into account the following reaction.<smiles>CC(=O)N=C1C=CC(=O)C=C1</smiles>

Benzoquinone product (Fig. S9 supporting document). Benzoquinone is mainly used for the synthesis of hydroquinone. Presence of PTS was confirmed by addition of xanthydrol to yield the corresponding $N$-xanthyl- $p$-toluenesulfonamide and detected by TLC $[57,58]$.

\subsubsection{Effect of CAT}

At constant concentrations of all the reactants i.e. [PA], $[\mathrm{NaOH}]$, [catalyst], and temperature, where $[\mathrm{PA}]\rangle[\mathrm{CAT}]$, plot of log[CAT] versus time were linear, indicated a first order dependence of rate on [CAT] for alkaline medium. The order of reaction in each reactant was determined using a log-log plot of $k$ versus concentration of the reactant. The linearity of the plots of $(-\mathrm{dc} / \mathrm{dt})$ versus [CAT] (Table 1, Figs. S2 and S3) was linear passing through the origin shows the order in [CAT] was found to be unity in the reactions.

\subsubsection{Effect of PA}

At lower concentration of [PA], the rate of reaction followed first order kinetics and shifted to zero order at its higher concentration. This is also obvious from the plot of $(-\mathrm{dc} / \mathrm{dt}$ ) versus [PA] (Tables 1, 2, Figs. S3 and S4), indicating first order at their lower concentration and tending towards zero order at their higher concentration.

\subsubsection{Effect of catalyst}

To obtain the optimal $\mathrm{Cu}(\mathrm{II}) / \mathrm{Ni}(\mathrm{II})$ concentration, experiments were conducted at several combination of catalyst,

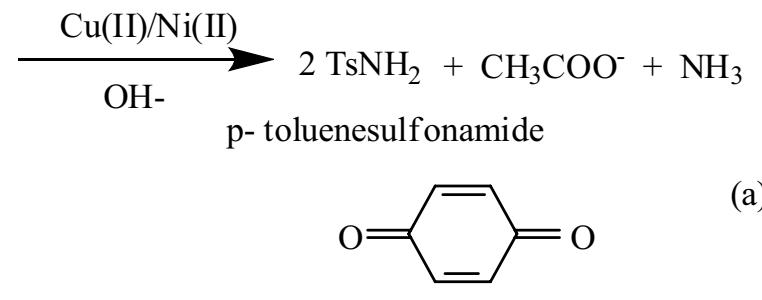

Benzoquinone
The main reaction product was identified as Benzoquinone. It was further confirmed by GC-MS analysis, which has been done by JEOL-JMS (Mate-MS system, Japan). The mass spectrum showed a molecular peak confirming and it was observe that rate of reaction increases as the concentration of catalyst increases. So, both Cu(II) (Table 1, Fig. S1) and Ni(II) (Table 1, Fig. S4) followed first order kinetics. 
Table 1 Effect of variation of [CAT], [PA], [Ni(II)], and $\left[\mathrm{OH}^{-}\right]$ on the rate of oxidation of paracetamol at $308 \mathrm{~K}$

\begin{tabular}{|c|c|c|c|c|c|c|}
\hline $\begin{array}{l}\text { [CAT] } \times 10^{3} \\
\left(\mathrm{~mol} \mathrm{dm} \mathrm{dm}^{-3}\right)\end{array}$ & $\begin{array}{l}{[\mathrm{PA}] \times 10^{2}} \\
\left(\mathrm{~mol} \mathrm{dm}{ }^{-3}\right)\end{array}$ & $\begin{array}{l}{[\mathrm{Ni}(\mathrm{II})] \times 10^{5}} \\
\left(\mathrm{~mol} \mathrm{dm} \mathrm{dm}^{-3}\right)\end{array}$ & $\begin{array}{l}{[\mathrm{OH}] \times 10^{3}} \\
\left(\mathrm{~mol} \mathrm{dm}{ }^{-3}\right)\end{array}$ & $k_{1} \times 10^{4}\left(\mathrm{~s}^{-1}\right)$ & $k_{\text {(cal) }} \times 10^{4}\left(\mathrm{~s}^{-1}\right)$ & $k_{(\exp )} \times 10^{4}\left(\mathrm{~s}^{-1}\right)$ \\
\hline 0.20 & 1.00 & 8.00 & 1.00 & 2.00 & - & - \\
\hline 0.40 & 1.00 & 8.00 & 1.00 & 2.00 & - & - \\
\hline 0.60 & 1.00 & 8.00 & 1.00 & 2.03 & - & - \\
\hline 0.80 & 1.00 & 8.00 & 1.00 & 2.06 & - & - \\
\hline 1.00 & 1.00 & 8.00 & 1.00 & 2.20 & - & - \\
\hline 1.20 & 1.00 & 8.00 & 1.00 & 2.18 & - & - \\
\hline 1.00 & 0.20 & 8.00 & 1.00 & 0.63 & 0.60 & 0.69 \\
\hline 1.00 & 0.40 & 8.00 & 1.00 & 1.31 & 1.15 & 1.07 \\
\hline 1.00 & 0.60 & 8.00 & 1.00 & 1.47 & 1.66 & 1.37 \\
\hline 1.00 & 0.80 & 8.00 & 1.00 & 1.89 & 2.13 & 1.64 \\
\hline 1.00 & 1.00 & 8.00 & 1.00 & 2.20 & 2.56 & 1.89 \\
\hline 1.00 & 1.20 & 8.00 & 1.00 & 2.63 & 2.96 & 2.12 \\
\hline 1.00 & 1.60 & 8.00 & 1.00 & 2.84 & 3.69 & 2.54 \\
\hline 1.00 & 1.00 & 2.00 & 1.00 & 0.52 & 0.64 & 0.46 \\
\hline 1.00 & 1.00 & 4.00 & 1.00 & 1.05 & 1.28 & 9.39 \\
\hline 1.00 & 1.00 & 6.00 & 1.00 & 1.47 & 1.90 & 1.41 \\
\hline 1.00 & 1.00 & 8.00 & 1.00 & 2.20 & 2.56 & 1.89 \\
\hline 1.00 & 1.00 & 12.0 & 1.00 & 3.26 & 3.84 & 2.85 \\
\hline 1.00 & 1.00 & 16.0 & 1.00 & 4.52 & 5.12 & 3.82 \\
\hline 1.00 & 1.00 & 20.0 & 1.00 & 5.20 & 6.40 & 4.79 \\
\hline 1.00 & 1.00 & 8.00 & 0.50 & 7.00 & 4.30 & 5.93 \\
\hline 1.00 & 1.00 & 8.00 & 0.60 & 3.79 & 3.80 & 4.10 \\
\hline 1.00 & 1.00 & 8.00 & 0.80 & 2.52 & 3.06 & 2.65 \\
\hline 1.00 & 1.00 & 8.00 & 1.00 & 2.20 & 2.56 & 1.89 \\
\hline 1.00 & 1.00 & 8.00 & 1.20 & 1.66 & 2.20 & 1.43 \\
\hline 1.00 & 1.00 & 8.00 & 1.60 & 1.05 & 1.72 & 0.93 \\
\hline 1.00 & 1.00 & 8.00 & 2.00 & 0.71 & 1.40 & 0.66 \\
\hline
\end{tabular}

Bold values define effect of various concentrations of reactants while other being constant

\subsubsection{Effect of $\mathrm{NaOH}$}

With increasing the concentration of $\left[\mathrm{OH}^{-}\right]$the value of reaction rate decreased, which is also evident from the plot of $(-\mathrm{dc} / \mathrm{dt})$ versus $\left[\mathrm{OH}^{-}\right]$in both catalyzed system (Tables 1, 2, Figs. S1 and S2). This shows negative effect of $\left[\mathrm{OH}^{-}\right]$on the oxidation of paracetamol.

\subsubsection{Effect of PTS}

Addition of the $p$-toluene sulphonamide (PTS) in the reaction mixture showed that the rate of reaction decreased with increasing [PTS] (Tables S1 and S2, Figs. S1 and S2).

Variations of ionic strength of the medium, and $\left[\mathrm{Cl}^{-}\right]$ suggesting an unchanged form to degrade PA under the constant experimental conditions. The rate of reaction increased with increasing in dielectric constant of the medium (Tables S1 and S2). The reaction was performed at different temperatures and the activation energies $\left(E_{a}\right)$ were calculated for both $\mathrm{Cu}(\mathrm{II})$ and $\mathrm{Ni}$ (II) catalyzes system. With the help of the energy of activation, values of the other activation parameters such as enthalpy of activation $\left(\Delta \mathrm{H}^{\#}\right)$, entropy of activation $\left(\Delta \mathrm{S}^{\#}\right)$, Gibbs free energy of activation $\left(\Delta \mathrm{G}^{\sharp}\right)$ and Arrhenius factor $(\mathrm{A})$, were also calculated.

\subsubsection{Reactive species of CAT and catalyst}

The reactive species of CAT, responsible for the oxidation of $\mathrm{PA}$ is $\mathrm{HOCl}$, because it is successfully capable to explain all the kinetic results obtained among all other reactive species of CAT i.e. $\mathrm{TsNCl}_{2}, \mathrm{H}_{2} \mathrm{OCl}^{+}$in acidic medium, and $\mathrm{TsNHCl}, \mathrm{HOCl}$ and $\mathrm{TsNCl}^{-}$in alkaline medium $[17,18]$.

$\mathrm{TsNCl}^{-}+\mathrm{H}_{2} \mathrm{O} \stackrel{K_{x}}{\rightleftharpoons} \mathrm{TsNHCl}+\mathrm{OH}^{-}$

$\mathrm{TsNHCl}+\mathrm{H}_{2} \mathrm{O} \stackrel{K_{y}}{\rightleftharpoons} \mathrm{TsNH}_{2}+\mathrm{HOCl}^{-}$

$K_{\mathrm{y}}=4.21 \times 10^{-3}$ at $298 \mathrm{~K}$.

While, $\mathrm{Cu}(\mathrm{II})$ and $\mathrm{Ni}(\mathrm{II})$ exist as same.

In reaction scheme 1 , Firstly reactive oxygen species $\mathrm{HOCl}\left(C_{1}\right)$ was generated with the PTS, this $\mathrm{HOCl}(\mathrm{C} 1)$ reacts 
Table 2 Effect of variation of [CAT], [PA], [Cu(II)], and [OH $\left.{ }^{-}\right]$ on the rate of oxidation of paracetamol at $308 \mathrm{~K}$

\begin{tabular}{|c|c|c|c|c|c|c|}
\hline $\begin{array}{l}{[\mathrm{CAT}] \times 10^{3}} \\
\left.(\mathrm{~mol} \mathrm{dm})^{-3}\right)\end{array}$ & $\begin{array}{l}{[\mathrm{PA}] \times 10^{2}} \\
\left(\mathrm{~mol} \mathrm{dm}{ }^{-3}\right)\end{array}$ & $\begin{array}{l}{[\mathrm{Cu}(\mathrm{II})] \times 10^{6}} \\
\left(\mathrm{~mol} \mathrm{dm}{ }^{-3}\right)\end{array}$ & $\begin{array}{l}\left.\mathrm{OH}^{-}\right] \times 10^{3} \\
\left(\mathrm{~mol} \mathrm{dm}^{-3}\right)\end{array}$ & $k_{1} \times 10^{4}\left(\mathrm{~s}^{-1}\right)$ & $k_{\text {(cal) }} \times 10^{4}\left(\mathrm{~s}^{-1}\right)$ & $k_{(\exp )} \times 10^{4}\left(\mathrm{~s}^{-1}\right)$ \\
\hline 0.20 & 1.00 & 8.00 & 1.00 & 2.00 & 2.43 & - \\
\hline 0.40 & 1.00 & 8.00 & 1.00 & 2.20 & 2.50 & - \\
\hline 0.60 & 1.00 & 8.00 & 1.00 & 2.33 & 2.43 & - \\
\hline 0.80 & 1.00 & 8.00 & 1.00 & 2.06 & 2.58 & - \\
\hline 1.00 & 1.00 & 8.00 & 1.00 & 2.17 & 2.50 & - \\
\hline 1.20 & 1.00 & 8.00 & 1.00 & 2.08 & 2.53 & - \\
\hline 1.00 & 0.20 & 8.00 & 1.00 & 0.52 & 0.57 & 0.65 \\
\hline 1.00 & 0.40 & 8.00 & 1.00 & 1.05 & 1.12 & 1.25 \\
\hline 1.00 & 0.60 & 8.00 & 1.00 & 1.47 & 1.59 & 1.80 \\
\hline 1.00 & 0.80 & 8.00 & 1.00 & 1.89 & 2.10 & 2.32 \\
\hline 1.00 & 1.00 & 8.00 & 1.00 & 2.24 & 2.34 & 2.80 \\
\hline 1.00 & 1.20 & 8.00 & 1.00 & 2.42 & 2.50 & 3.27 \\
\hline 1.00 & 1.60 & 8.00 & 1.00 & 2.52 & 2.75 & 4.00 \\
\hline 1.00 & 1.00 & 2.00 & 1.00 & 0.63 & 0.52 & 0.81 \\
\hline 1.00 & 1.00 & 4.00 & 1.00 & 1.47 & 0.97 & 1.51 \\
\hline 1.00 & 1.00 & 6.00 & 1.00 & 1.84 & 1.91 & 2.23 \\
\hline 1.00 & 1.00 & 8.00 & 1.00 & 2.20 & 2.34 & 2.80 \\
\hline 1.00 & 1.00 & 10.0 & 1.00 & 2.63 & 2.84 & 3.31 \\
\hline 1.00 & 1.00 & 14.0 & 1.00 & 3.15 & 3.21 & 4.42 \\
\hline 1.00 & 1.00 & 16.0 & 1.00 & 3.36 & 3.41 & 4.88 \\
\hline 1.00 & 1.00 & 20.0 & 1.00 & 3.51 & 3.70 & 5.71 \\
\hline 1.00 & 1.00 & 8.00 & 0.20 & 8.31 & 11.8 & 8.80 \\
\hline 1.00 & 1.00 & 8.00 & 0.40 & 5.68 & 7.54 & 5.81 \\
\hline 1.00 & 1.00 & 8.00 & 0.60 & 3.79 & 3.45 & 4.32 \\
\hline 1.00 & 1.00 & 8.00 & 0.80 & 2.84 & 2.50 & 3.45 \\
\hline 1.00 & 1.00 & 8.00 & 1.00 & 2.18 & 2.34 & 2.80 \\
\hline 1.00 & 1.00 & 8.00 & 1.20 & 2.00 & 1.84 & 2.45 \\
\hline 1.00 & 1.00 & 8.00 & 1.60 & 1.47 & 1.30 & 1.91 \\
\hline 1.00 & 1.00 & 8.00 & 2.00 & 0.94 & 0.82 & 1.50 \\
\hline
\end{tabular}

Bold values define effect of various concentrations of reactants while other being constant with PA to form a complex between involves chlorine transfer through the intermediacy of $\mathrm{HOCl}$. The protonated oxidant species $\mathrm{HOCl}$ formed from $\mathrm{TsNHCl}$ reacts with the substrate in a fast equilibrium step to form the substrateCAT complex $\left(C_{2}\right)$ with the elimination of hydroxide ion. The inverse negative order in $\left[\mathrm{OH}^{-}\right]$might also be due to this reason. In the pre rate determining step, this $\mathrm{C}_{2}$ complex, combines with a molecule of catalyst $(\mathrm{Cu}(\mathrm{II}) / \mathrm{Ni}(\mathrm{II}))$ to give an intermediate complex $\mathrm{C}_{3}$, which decomposes in a slow step to produce the intermediate species by the regeneration of catalyst and no intervention of the free radical was observed. One more molecule of CAT further reacts with an intermediate in a fast step to yield products.

\subsection{Spectral evidence}

UV-VIS spectra of paracetamol, CAT and mixture of both, verified the complex formation between oxidant (CAT) and substrate (PA). Maximum absorption occurred at $245 \mathrm{~nm}$ for paracetamol, $225 \mathrm{~nm}$ for CAT, and $230 \mathrm{~nm}$ for PA-CAT. It was further confirmed by $15 \mathrm{~nm}$ of hypsochromic shift from 245 to $230 \mathrm{~nm}$ of paracetamol (Figs. 1, 2). The formation of complex between catalyst and CAT-PA mixture was also evidenced spectra of both CAT-paracetamol and CAT-PA-catalyst in which a shift of CAT-PA from 230 to $225 \mathrm{~nm}$.

According to the reaction scheme 1 (supporting document) and considering the fact that $1 \mathrm{~mol}$ of PA is oxidized by $2 \mathrm{~mol}$ of CAT, the rate expressed as:

rate $=(\mathrm{R})=-\frac{\mathrm{d}[\mathrm{CAT}]}{\mathrm{dt}}=2 k\left[\mathrm{C}_{3}\right]$

$\mathrm{R}=\frac{2 k K_{1} K_{2} K_{3}[\mathrm{PA}][\text { catalyst }][\mathrm{CAT}]_{\mathrm{T}}}{\left[\mathrm{OH}^{-}\right]\left[\mathrm{TsNH}_{2}\right]+K_{1}\left[\mathrm{OH}^{-}\right]+K_{1} K_{2}[\mathrm{PA}]+K_{1} K_{2} K_{3}[\mathrm{PA}][\text { catalyst }]}$ 


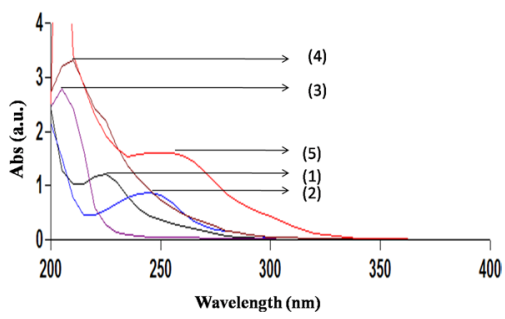

Fig. 1 Reaction conditions: (1) $[\mathrm{CAT}]=1 \times 10^{-4} \mathrm{~mol} \mathrm{dm}^{-3}$; (2) $[\mathrm{PA}]=1 \times 10^{-4} \mathrm{~mol} \mathrm{dm}{ }^{-3}$; (3) $[\mathrm{Cu}(\mathrm{II})]=8 \times 10^{-6} \mathrm{~mol} \mathrm{dm}^{-3}$, $\left[\mathrm{OH}^{-}\right]=1 \times 10^{-3} \mathrm{~mol} \quad \mathrm{dm}^{-3} ;$ (4) $\left[\right.$ CAT] $=1 \times 10^{-4} \mathrm{~mol} \mathrm{dm} \mathrm{dm}^{-3}$, $[P A]=1 \times 10^{-4} \mathrm{~mol} \quad \mathrm{dm}^{-3} ; \quad(5) \quad[C A T]=1 \times 10^{-4} \quad \mathrm{~mol} \quad \mathrm{dm}^{-3}$, $[\mathrm{PA}]=1 \times 10^{-4} \mathrm{~mol} \mathrm{dm}^{-3},[\mathrm{Cu}(\mathrm{II})]=8 \times 10^{-6} \mathrm{~mol} \mathrm{dm}^{-3},\left[\mathrm{OH}^{-}\right]=1 \times 10^{-3}$ $\mathrm{mol} \mathrm{dm} \mathrm{m}^{-3}$

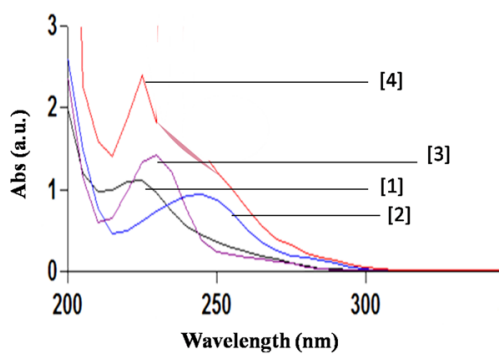

Fig. 2 Reaction conditions: (1) [CAT] $=1 \times 10^{-4} \mathrm{~mol} \mathrm{dm} \mathrm{dm}^{-3}$; (2) $[\mathrm{PA}]=1 \times 10^{-4} \mathrm{~mol} \mathrm{dm}{ }^{-3}$; (3) $[\mathrm{Ni}(\mathrm{II})]=8 \times 10^{-5} \mathrm{~mol} \mathrm{dm}^{-3}$, $\left[\mathrm{OH}^{-}\right]=1 \times 10^{-3} \mathrm{~mol} \mathrm{dm}^{-3} ;$ (4) $[\mathrm{CAT}]=1 \times 10^{-4} \mathrm{~mol} \mathrm{dm^{-3 }}$, $[\mathrm{PA}]=1 \times 10^{-4} \mathrm{~mol} \quad \mathrm{dm}^{-3} ; \quad$ (5) $[\mathrm{CAT}]=1 \times 10^{-4} \mathrm{~mol} \quad \mathrm{dm}^{-3}$, $[\mathrm{PA}]=1 \times 10^{-4} \mathrm{~mol} \mathrm{dm}^{-3},[\mathrm{Ni}(\mathrm{II})]=8 \times 10^{-5} \mathrm{~mol} \mathrm{dm}^{-3},\left[\mathrm{OH}^{-}\right]=1 \times 10^{-3}$ $\mathrm{mol} \mathrm{dm} \mathrm{m}^{-3}$

where, catalyst $=\mathrm{Cu}(\mathrm{II}) / \mathrm{Ni}(\mathrm{II})$.

Equation (2) is the rate law on the basis of which observed kinetic orders with respect to each reactant of the reaction can very easily be explained.

On reversing Eq. (2), we have Eq. (3)

$$
\begin{aligned}
\frac{[\mathrm{CAT}]_{\mathrm{T}}}{\text { rate }}= & \frac{\left[\mathrm{OH}^{-}\right]\left[\mathrm{TsNH}_{2}\right]}{2 k K_{1} K_{2} K_{3}[\mathrm{PA}][\text { Catalyst }]}+\frac{\left[\mathrm{OH}^{-}\right]}{2 k K_{2} K_{3}[\mathrm{PA}][\text { Catalyst }]} \\
& +\frac{1}{2 k K_{3}[\text { Catalyst }]}+\frac{1}{2 k}
\end{aligned}
$$

Equation (3), indicates that if a plot is made between $[\mathrm{CAT}]_{\mathrm{T}} /$ rate and $\left[\mathrm{OH}^{-}\right]$or $\left[\mathrm{TsNH}_{2}\right]$ or $1 /[\mathrm{PA}]$ or $1 /[\mathrm{Cu}(\mathrm{II}) /$ $\mathrm{Ni}(\mathrm{II})]$ straight lines with positive intercepts on $y$-axis will be obtained (Figs. S5, S6, S7, S8), and prove the proposed reaction scheme on the basis of which the rate law (2) has been derived. From the values of the intercept and slope of the plots, the values of $k_{1}, K_{1}, K_{2}$ and $K_{3}$ have been calculated and found to be $5.05 \times 10^{-4} \mathrm{~s}^{-1}, 1.83 \times 10^{-4} \mathrm{~mol} \mathrm{dm}^{-3}$, $9.9 \times 10^{-2} \mathrm{~mol}^{-1} \mathrm{dm}^{3}$ and 339.59 respectively.

\section{Comparative study}

Present paper is compared the experimental findings with earlier work done in the presence of $\operatorname{Ir}(\mathrm{III}), \mathrm{Ru}(\mathrm{III}), \mathrm{Pd}(\mathrm{II})$ catalyst in acidic and alkaline medium for the degradation of paracetamol. The reactive species of CAT is $\mathrm{HOCl}$ in $\operatorname{Ir}(I I I)$, and $\mathrm{Ru}(\mathrm{III})$ catalysts, but $\mathrm{TsNHCl}$ was the reactive species of CAT in the Pd(II) catalyzed oxidation of PA in an acidic medium. All catalysts have first- to zero-order kinetics with respect to the concentration of PA. The order with respect to the catalyst in present paper followed first order.

Furthermore, efforts were made to compare the finding of this paper with the results reported for the $\operatorname{Ir}(I I I)$ [17], Ru(III) [18], and Pd(II) [25] catalyzed oxidation of PA by CAT in an acidic, and alkaline medium. It can be seen from Table S3, that the activation energy is the highest for the slowest reaction in the Pd(II) catalyzed oxidation of PA in an acidic medium. From the given rate constants and energies of activation, the relative reactivity of the catalysts for the oxidation of PA by CAT is in the order: $\operatorname{Ir}(\mathrm{III})$ acidic $>\mathrm{Cu}$ (II) alkaline $>\mathrm{Ru}$ (III) acidic $>\mathrm{Pd}$ (II) alkaline medium $>\mathrm{Ni}$ (II) alkaline $>\mathrm{Pd}$ (II) acidic medium. $\mathrm{Pd}(\mathrm{II})$ has $\mathrm{d}^{8}$ electronic configuration, and is expected to have the least catalytic efficiency among the catalysts used.

\section{Conclusions}

Oxidation of paracetamol by CAT in catalytic system and in alkaline medium at $308 \mathrm{~K}$ was successfully carried out. In the absence of catalyst reaction is sluggish but catalyst helps to increase the oxidation process. Above results also reveal that both the catalyst $\mathrm{Ni}(\mathrm{II})$ and $\mathrm{Cu}$ (II) showed same catalytic behavior for oxidation of paracetamol. Obtained results have been clearly demonstrated by conceivable mechanism and the related law has been deduced. Three results i.e. experimental $\left(k_{1}\right)$, calculated from rate law $\left(k_{\text {cal }}\right)$ and by use of regression analysis $\left(k_{\text {exp }}\right)$, support the rate law and reaction mechanism.

Acknowledgements We are grateful to DST-FIST for instrumental facilities, and UGC (New Delhi) provided financial support (Women Post Doctoral Fellowship) by research project grant (No. F.15-1/2013-14/ PDFWM-2013-14-GE-CHH-18784(SA-II)).

\section{Compliance with ethical standards}

Conflict of interest On behalf of all authors, I states that there is no conflict of interest. 


\section{References}

1. Korth A, Fiebiger C, Bornmann K, Schmidt W (2004) NOM increase in drinking water reservoirs-relevance for drinking water production. Water Sci Technol Water Supply 4:55-60

2. Eikebrokk B, Vogt RD, Liltved H (2004) NOM increase in Northen European source waters: discussion of possible causes and impact on coagulation/contact filtration process. Water Sci Technol Water Supply 4:47-54

3. Muller S, Schlatter C (1998) Estrogenic potency of nonylphenol in vivo-a case study to evaluate the relevance of human non occupational exposure. Pure Appl Chem 70:1847-1853

4. Ustun AP, Corvalan C (2006) Preventing disease through healthy environments: towards an estimate of the environmental burden of disease. WHO, Geneva, pp 1-104

5. Shannon MA, Bohn PW, Elimelech M, Georgiadis JG, Mrinas BJ, Mayes AM (2008) Science and technology for water purification in the coming decades. Nature 452:301-310

6. Martz M (2012) Effective waste water treatment in the pharmaceutical industry. Eng Des 32(6):1-12

7. Chelliapan S, Wilby T, Salis PJ (2006) Performance of an upflow anaerobic stage reactor (UASR) in the treatment of pharmaceutical waste water containing macrolide antiobiotics. Water Res 40(3):507-516

8. Kong SH, Watts RJ, Choi JH (1998) Treatment of petroleum-contaminated soil using iron mineral catalyzed hydrogen peroxide. Chemosphere 37:1437-1482

9. Tan BH, Teng TT, Omar AKM (2000) Removal of dyes and industrial dye wastes by magnesium chloride. Water Res 34:597-601

10. Dean JG, Bosqui FL, Lanouette KH (1972) Removing heavy metals from waste water. Environ Sci Technol 6(6):518-522

11. Kamali M, Khodaparast Z (2015) Review on recent developments on pulp and paper mill wastewater treatment. Ecotoxicol Environ Saf 114:326-342

12. Behara J, Behara B (2018) Kinetics and mechanism of interaction of cis-Diauabis(oxalate)chromate(III) with cefoperazone in aqueous medium:as an antibacterial study. J Pharm Innov. https ://doi.org/10.1007/s12247-018-9368-3

13. Pourakbar M, Moussavi G, Shekoohiyan S (2016) Homogeneous VUV advanced oxidation process for enhanced degradation and mineralization of antibiotics in contaminated water. Ecotoxicol Environ Saf 125:72-77

14. An T, Yang H, Li G, Song W, Cooper WJ, Nie X (2010) Kinetics and mechanism of advanced oxidation process (AOP's) in degradation of ciprofloxacin in water. Appl Catal B 94:288-294

15. Yin L, Ma R, Wang B, Yuan H, Yu G (2017) The degradation and persistence of five pharmaceuticals in an artificial climate incubator during a one year period. RSC Adv 7:8280-8287

16. Huo S, Dong J, Song C, Xu J, Shen S, Ren Y, Shi T (2014) Characterization of the reaction products, kinetic and mechanism of oxidation of the drug captopril by platinum (IV) complexes. RSC Adv 4:7402-7409

17. Singh AK, Negi R, Katre YR, Singh SP (2009) Mechanistic study of novel oxidation of paracetamol by chloramine-T using microamount of chloro-complex of $\operatorname{Ir}(\mathrm{III})$ as a homogeneous catalyst in acidic medium. J Mol Catal A Chem 302:36-42

18. Singh AK, Negi $R$, Jain B, Katre YR, Singh SP, Sharma VK (2009) Kinetics and mechanism of Ru(III)-catalyzed oxidation of paracetamol by chloramine-T in aqueous acidic medium. Catal Lett 132:285-291

19. Yang L, Yu LE, Ray MB (2009) Photocatalytic oxidation of paracetamol: dominant reactants, intermediates, and reaction mechanisms. Environ Sci Technol 43:460-465

20. Mulla RM, Basavaraj G (2006) Kinetics of ruthenium(III)-catalysed oxidation of paracetamol by diperiodatonickelate(IV) in aqueous alkaline medium (stopped flow technique). Appl Catal A 314:208-215

21. Kiran TS, Hiremath CV (2006) Kinetic, mechanistic and spectral investigations of ruthenium(III)/osmium(VIII)-catalysed oxidation of paracetamol by alkaline diperiodatoargentate(III) (stopped flow technique). Appl Catal A 305:79-89

22. Kiran TS, Hiremath DC, Nandibewoor ST (2007) Oxidation of N-(4-hydroxyphenyl) acetamide (paracetamol) drug by diperiodatocuprate(III) in aqueous alkaline medium by stopped flow technique. Z Phys Chem 221:501-517

23. Andreozzi R, Caprio V, Marotta R, Vogna D (2003) Paracetamol oxidation from aqueous solutions by means of ozonation and $\mathrm{H}_{2} \mathrm{O}_{2}$ /UV system. Water Res 37:993-1004

24. Skoumal M, Cabot PL, Centellas F, Arias C, Rodrıguez RM, Garrido JA, Brillas E (2006) Mineralization of paracetamol by ozonation catalyzed with $\mathrm{Fe}^{2+}, \mathrm{Cu}^{2+}$ and UVA light. Appl Catal B 66(3-4):228-240

25. Singh AK, Negi R, Jain B, Katre YR, Singh SP, Sharma VK (2011) $\mathrm{Pd}$ (II) Catalyzed oxidative degradation of paracetamol by chloramine-T in acidic and alkaline media. Ind Eng Chem Res 50(14):8407-8419

26. Jallouli N, Elghniji K, Trabelsi H, Ksibi M (2017) Photocatalytic degradation of paracetamol on $\mathrm{TiO}_{2}$ nanoparticles and $\mathrm{TiO}_{2} /$ cellulosic fiber under UV and sunlight irradiation. Arab J Chem 10(2):S3640-S3645

27. Tambosi JL, Yamanaka LY, Jose HJ, Moreira RDFPM, Schroder HF (2010) Recent research data on the removal of pharmaceuticals from sewage treatment plants (STP). Quim Nova. https://doi. org/10.1590/S0100-40422010000200032

28. Spanswick J, Ingold KU (1970) Halogenation with $N$-haloamines in strong acid. I. the nature of the chain of propagating radical. Can J Chem 48(4):546-553

29. Nishiwaki N (2014) Methods and applications of cycloaddition reaction in organic syntheses. Wiley, Hoboken

30. Murai K, Matsuura K, Aoyama H, Fujioka H (2016) Oxidative rearrangement via in situ generated $\mathrm{N}$-chloramine: synthesis of fused tetra hydro isoquinolines. Org Lett 18(6):1314-1317

31. Filler R (1963) Oxidations and dehydrogenations with N-Bromosuccinimide and related $N$-haloimides. Chem Rev 63:21-43

32. Mathur NK, Narang CK (1975) The determination of organic compounds with $\mathrm{N}$-bromosuccinimide and allied reagents. Academic Press, London

33. Campbell MM, Johnson G (1978) Chloramine $T$ and related $\mathrm{N}$-halogeno-N-metallo reagents. Chem Rev 78:65-79

34. Mythily CK, Rangappa KS, Gowda NMM (1991) Kinetics and mechanism of chloramine-T oxidation of cinnamaldehyde in two acid media. Int J Chem Kinet 23(2):127-136

35. Saldanha RJD, Ananda S, Venkatesha BM, Gowda NMM (2002) Oxidation of psycotropic drug by chloramine-T in acidic media: a kinetic study using spectrophotometry. J Mol Struct 606:147-154

36. Mahadevappa DS, Rangappa KS, Gowda NMM, Gowda BT (1982) Kinetic and mechanistic studies of oxidation of arginine, histidine and threonine in alkaline medium by N-chloro-N-sodio-ptolouenesulphonamide. Int J Chem Kinet 14:1183-1197

37. Puttaswamy, Nirmala V, Gowda JRV (2008) Mechanistic investigations of oxidation of some dipeptides by sodium N-chlorop-toluenesulfonamide in alkaline medium: a kinetic study. Can J Chem 26:536-542

38. Vinod KN, Puttaswamy, Gowda NN (2009) Mechanistic aspects for the oxidation of sunset yellow dye by chloramine-T in presence of perchloric acid and in sodium hydroxide medium catalyzed by Os(VIII): a spectrophotometric kinetic approach. Inorg Chim Acta 362:2044-2051

39. Puttaswamy, Jagadeesh RV (2006) "Mechanistic studies of oxidation of thiols to disulfides by sodium 
$\mathrm{N}$-Chloro-p-toluenesulfonamide in an alkaline medium: a kinetic approach. Ind Eng Chem Res 45:1563-1570

40. Puttaswamy, Jagadeesh RV (2005) Kinetics of oxidation of pantothenic acid by chloramine- $\mathrm{T}$ in perchloric acid and in alkaline medium catalyzed by $\mathrm{OsO}_{4}$ : a mechanistic approach. Int J Chem Kinet 37(4):201-210

41. Singh AK, Sachdev N, Srivastava A, Katre YR, Singh SP (2010) "A novel and facile oxidation of $D$-glucose by $N$-bromophthalimide in the presence of chloro complex of Ru(II). Synth React Inorg Met-Org Nano-Met Chem 40:947-954

42. Singh AK, Sachdev N, Srivastava A, Jain B, Katre YR (2012) Oxidation of $\mathrm{D}$-glucose by $\mathrm{N}$-bromophthalimide in the presence of chlorocomplex of Ir(III): a kinetic and mechanistic study. Res Chem Intermed 38:507-521

43. Sachdev N, Singh AK, Srivastava A, Katre YR (2013) Kinetic and mechanistic study of chloro complex of Ru(III) and Ir(III) catalyzed oxidation of $\mathrm{D}$-fructose by $\mathrm{N}$-bromophthalimide in acidic medium. J Saudi Chem Soc. https://doi.org/10.1016/j. jscs.2012.12.006

44. Singh AK, Jain B, Negi R, Katre YR, Singh SP, Sharma VK (2009) Kinetics and mechanism of oxidation of glycine by $\mathrm{N}$-bromophthalimide in the presence of chloro complex of $\operatorname{Ir}(\mathrm{III})$ as homogeneous catalyst. Oxid Commun 32(1):350-355

45. Singh AK, Jain B, Negi R, Katre YR, Singh SP (2009) Oxidation of valine by $\mathrm{N}$-bromophthalimide in presence of chloro complex of $\mathrm{Pd}(\mathrm{II})$ as homogeneous catalyst: a kinetic and mechanistic study. Open Catal J 2:12-20

46. Singh AK, Jain B, Negi R, Katre YR, Singh SP, Sharma VK (2010) Kinetic study of oxidation of valine by $N$-bromophthalimide in the presence of $\operatorname{Ir}(\mathrm{III})$ chloride as homogeneous catalyst. Synth React Inorg Met-Org Nano-Met Chem 40:71-77

47. Singh AK, Jain B, Negi R, Katre YR, Singh SP, Sharma VK (2009) A novel oxidation of valine by $\mathrm{N}$-bromophthalimide in the presence of ruthenium (III) chloride as homogeneous catalyst. Catal Lett 131:98-104

48. Singh AK, Jain B, Negi R, Katre $Y R$, Singh SP, Sharma VK (2009) Kinetics and mechanism of oxidation of $\beta$-alanine by $\mathrm{N}$-bromophthalimide in the presence of $\mathrm{Ru}$ (III) chloride as homogeneous catalyst in acidic medium. Transit Met Chem 34:521-528

49. Singh AK, Jain B, Negi $R$, Katre $Y R$, Singh SP, Sharma VK (2015) Mechanistic study of $\left[\mathrm{RuCl}_{3}\left(\mathrm{H}_{2} \mathrm{O}\right)_{2} \mathrm{OH}\right]^{-}$catalyzed oxidation of L-leucine by acidic $\mathrm{N}$-bromophthalimide. J Iran Chem Soc 12:1717-1728

50. Sachdev N, Singh AK, Katre YR (2014) Mechanistic study of $\mathrm{D}$-arabinose by $\mathrm{N}$-bromophthalimide in the presence of micro amount of chloro complex of Ru(III) as a homogeneous catalyst. Arab J Chem (in press)

51. Yuan-yuan A, Zheng D, Wu J (2014) An unexpected copper(II)catalyzed three-component reaction of quinazoline 3-oxide, alkylidenecyclopropane, and water. Chem Commun 50:9165-9167

52. Corey EJ, Mock WL, Pasto DJ (1961) Chemistry of diimide: some new systems for the hydrogenation of multiple bonds. Tetrahedron Lett 11:347-352

53. Tazwar G, Jain A, Mittal N, Devra V (2017) Oxidation of ciprofloxacin by hexacynoferrate(III) in the presence of $\mathrm{Cu}$ (II) as a catalyst: a kinetic study. Int J Chem Kinet 49:534-542
54. Lister MW (1953) The stability of some complexes of trivalent copper. Can J Chem 31:638-652

55. Gray ET, Taylor JRW, Margerum DW (1977) Kinetics and mechanisms of the copper-catalyzed decomposition of hypochlorite and hypobromite. Properties of a dimeric copper(III) hydroxide intermediate. Inorg Chem 16:3047-3055

56. Grases F, Amat E, Palou J (1987) Kinetics and mechanism of the oxidation of diphenylamine by $\mathrm{Tc}(\mathrm{VII})$ catalyzed by the $\mathrm{Cu}(\mathrm{II})$ ion. J Mol Catal A Chem 40:305-310

57. Hahn EA, Peters E (1961) The kinetics and mechanism of the $\mathrm{Cu}^{++}$- catalyzed reduction of $\mathrm{Cr}(\mathrm{VI})$ by hydrogen in aqueous solutions. Can J Chem 39:162-170

58. Byerley JJ, Lee JYH (1967) Copper(II)-catalyzed oxidation of carbon monoxide by molecular oxygen. Can J Chem 45:3025-3030

59. Church JA (1994) Kinetics of the uncatalyzed and copper(II)-catalyzed decomposition of sodium hypochlorite. Ind Eng Chem Res 33:239-245

60. Bontchev PR, Gantcheva S (1980) Mechanism of the copper(II)catalysed peroxide oxidation of $\mathrm{m}$-aminobenzoic acid and 1,3,5-trihydroxybenzene used for analytical purposes. Talanta 27:899-904

61. Jha S, Sharma PD, Gupta YK (1983) Kinetics and mechanism of the copper(II)-catalyzed oxidation of lactic acid with chloramine T (CAT) in alkaline solutions. Inorg Chem 22:1393-1395

62. Krane MA (2004) Hydrodehalogenation of haloarenes over Silica supported Pd and $\mathrm{Ni}$ : a consideration of catalytic activity/selectivity and haloarene reactivity. Appl Catal A 271:109-118

63. Amorim C, Yuan G, Patterson PM, Keane MA (2005) Ni-Al hydrotalcite as an efficient and environmentally friendly solid catalyst for solvent-free liquid-phase selective oxidation of ethyl benzene to acetophenone with $1 \mathrm{~atm}$ of molecular oxygen. J Catal 234:268-281

64. Coloma F, Sepulveda-Escribano A, Fierro JLG, Rodriguez-Reinoso $F$ (1997) Gas phase hydrogenation of croton aldehyde over Pt/ Activated carbon catalysts, influence of the oxygen surface groups on the support. Appl Catal A 150:165-183

65. McMillan ST, Agrawal PK (1988) Gas-phase hydrogenation of butyronitrile over supported platinum catalysts. Ind Eng Chem Res 27:243-248

66. Khan AT, Mondal E, Sahu PR, Islam S (2003) Nickel(II) chloride as an efficient and useful catalyst for chemo selective thioa cetalization of aldehydes. Tetrahedron Lett 44:919-922

67. Brown KC, Yank SH, Kodedek T (1995) Highly specific oxidative cross linking of proteins mediated by a nickel-peptide complex. Biochemistry 34:4733-4739

68. Mack DP, Dervan PB (1990) Nickel-mediated sequence-specific oxidative cleavage of DNA by a designed metalloprotein. J Am Chem Soc 112:4604-4606

69. Mack DP, Dervan PB (1992) Sequence-specific oxidative cleavage of DNA by a designed metalloprotein, nickel(II).cntdot. GGH(Hin139-190). Biochemistry 31:9399-9405

70. Nagaoka M, Hagihara M, Kuwahara J, Sugiura Y (1994) A novel zinc finger-based DNA cutter: biosynthetic design and highly selective DNA cleavage. J Am Chem Soc 116:4085-4086

71. Muller JG, Hickerson RP, Perez RJ, Burrows CJ (1997) DNA damage from sulfite autoxidation catalyzed by a Nickel(II) peptide. J Am Chem Soc 119:1501-1506 
72. Liang Q, Ananias DC, Long EC (1998) Ni(II)·Xaa-Xaa-His induced DNA cleavage: deoxyribose modification by a common "activated" intermediate derived from KHSO5, MMPP or $\mathrm{H}_{2} \mathrm{O}_{2}$. J Am Chem Soc 120:248-257

73. Liang Q, Eason PD, Long EC (1995) Metallopeptide-DNA interactions: site-selectivity based on amino acid composition and chirality. J Am Chem Soc 117:9625-9631

74. Huang X, Pieczko ME, Long EC (1999) Combinatorial optimization of the DNA cleaving $\mathrm{Ni}(\mathrm{II}) \cdot$ Xaa-Xaa-His metallotripeptide domain. Biochemistry 38:2160-2166
75. Thendral P, Shailaja S, Ramachandran MS (2007) Nickel peroxide: a more probable intermediate in the $\mathrm{Ni}(\mathrm{II})$-catalyzed decomposition of peroxomonosulfate. Int J Chem Kinet 39:320-327

76. Ostrowski W, Karczewska K, Frański R (2013) Oxidation of paracetamol by $\mathrm{Cu}^{2+}$-formation of the paracetamol radical cation. Rapid Commun Mass Spectrom 27:1579-1584

Publisher's Note Springer Nature remains neutral with regard to jurisdictional claims in published maps and institutional affiliations. 